\title{
Health Status Change of English, French and Chinese Immigrants in Ottawa and Gatineau, Canada
}

\author{
Ning Tang*, Colin MacDougall \\ Discipline of Public Health, Flinders University, Australia
}

Copyright (C) 2015 Horizon Research Publishing All rights reserved.

\begin{abstract}
Background: Health status change of the immigrants is of particular interest to health researchers and policy-makers, because it can impact population health outcomes; English, French and Chinese speaking immigrants are main immigrant sub-groups in Canada. Objectives: The multicultural study aims at examining general Health Status Change of English, French and Chinese speaking immigrants in Ottawa and Gatineau, Canada, and identifying demographic factors that correlate with the change and impact the change. Methods: In total, 810 English, French and Chinese speaking immigrants in Ottawa and Gatineau, Canada were recruited by purposive-sampling. Using self-reports, respondents answered questions regarding general Health Status and Demography in a Multicultural Lifestyle Change Questionnaire of English, French or Chinese version. Data in Health Status Change were analyzed statistically in percentage, significance of difference, correlation and regression. Results: Immigrants of different gender, language and category sub-groups exhibited different Health Status Change Rates, Health Status Improving Rates and Health Status Declining Rates, but no statistical difference between the rates. Immigrant general Health Status Change was correlated positively with Age and Primary Occupation, and negatively with Income. Mother Tongue, Primary Occupation and Income significantly impacted Health Status Change. Conclusion: Immigrants of different sub-groups in Canada experienced different health status change. The results supported "healthy immigrant effect". The "decline in immigrant health status" over time existed in some of immigrant sub-groups. Data of immigrant health status change can provide evidence for health policy-making and policy-revising in Canada.
\end{abstract}

Keywords Immigration, Health Status Change, Healthy Immigrant Effect, Difference, Correlation, Impacting Factors

\section{Introduction}

Given that immigrants represent a large proportion of
Canadian population growth, their health status and health status change are of particular interest to health researchers, policy-makers, and program officials $[1,2]$, because demographic trends suggest that health status of immigrants and their descendants will play an increasingly central role in shaping population health outcomes (i.e. mortality or morbidity) of the immigrant country and immigrants potentially offer some significant analytical advantages for understanding the population health disparities in the host country [3]. Along with physically relocating to a new country, immigrants experienced transitions in many segments of their life that resulted in cultural, psychosocial, socio-economic, lifestyle and social support network changes [4]. The health status data (2001 - 2003) in Canada shows that recently arrived immigrants to Canada tended to be substantially healthier than Canadian-born population, corresponding to the "healthy immigrant effect" $[5,6]$.

The "healthy immigrant effect" is most likely due to a selective immigration process in which only people who have passed a medical screening exam are granted entry to Canada $[6,7]$. However, the healthy immigrant phenomenon does not last, with health status deteriorating with increased time in Canada [7], and converging toward native-born levels $[5,6,8,9,10]$.

Due to data limitations, there is little research on the disparities of health status among different gender, ethnic, cultural/linguistic and category sub-groups of immigrants in Canada [11], and no study has compared diversities of their health status in pre- and post-immigration phrases.

English speaking immigrants represent one of the largest ethnic or cultural immigrant sub-groups in Canada [12, 13], while French speaking immigrants are one of the principal immigrant sub-groups in the Ottawa (Ontario) - Gatineau (Québec) region [12, 13, 14]. Chinese speaking immigrants have constituted the largest immigrant sub-group entering Canada and one of the fastest-growing sub-groups in Canada since 1987, and are a larger sub-group in the region $[13,15$, $16]$.

The main objective of this study was to examine the differences in general Health Status Change among different sub-groups of the immigrants as well as to explore the relationships between Health Status Dependent Variable 
(Health Status Change) and Demographic Independent Variables (such as Mother Tongue, Age, Gender, Category of Immigration, Duration of Residence, Employment Status, Primary Occupation, Religion, Income). The examination shows far-reaching significance in multicultural health research, health care, health policy-making and health promoting program in Canada.

\section{Materials and Methods}

\subsection{Survey Method}

English, French and Chinese speaking immigrants at Adult Educational Centres/Schools, Christian Community Churches and Residential Communities in Gatineau and Ottawa were identified as the target population of this multicultural study. Random sampling was deemed impracticable for the study and could be biased because immigrant status of three language sub-groups could not be identified effectively according to the sampling criteria. Purposive-sampling methods were applied in the study to recruit the qualified immigrant participants.

Measurement of health status includes two main ways: self-reports of chronic conditions and self-reports of the general / overall status of one's health $[3,17]$. The later way was used to examine immigrant health status for assess their Health Status Change.

Immigrants of the first generation in Ottawa and Gatineau were defined as the participants in the multicultural study, who must have been 18 years or older, have resided in Ottawa or Gatineau one year or more, and had been 16 years or older when they arrived in Canada, for controlling confounders of the immigrant health status change study as far as possible. According to the rule of thumb that the number of subjects to item ratio in questionnaire should be at least 10:1 and the factors or characteristics of this multicultural study, at least 600 qualified and volunteer immigrants (respectively not less than 200 subjects for English, French and Chinese immigrant sub-groups) in the two cities were planned to recruit as the participants of this study, because more than 500 samples are very good for maintaining necessary precision of a survey based on the suggestion of some survey or research experts $[18,19]$. In total, 810 qualified participants $(278,268$ and 264 subjects respectively for English, French and Chinese immigrants) were recruited to the study. All participants answered questions relating to health status and demography in a Multicultural Lifestyle Change Questionnaire of English, French or Chinese version developed by the authors, with all responses self-reported. The Multicultural Lifestyle Change Questionnaire was demonstrated by a pilot-test in the three immigrant sub-groups to have high validity (Pearson correlation coefficient $\mathrm{r}=0.435>$ satisfactory value 0.40 ) $[20,21]$, and reliability (alpha coefficient $\alpha=0.754>$ satisfactory value 0.70 ) before the multicultural study [22].

Health Status Change (dependent variable) was identified based on the response choices of two health status questions before and after immigration in the Multicultural Lifestyle Change Questionnaire, which included question one "Before arrival in Canada, how would you estimate your overall health status?" and question two - "Since arrival in Canada, how would you estimate your overall health status?". Generally, self-perceived health is measured on a five-category scale: poor, fair, good, very good or excellent [5]. The self-reported health status of this multicultural study was measured on a seven-category scale. The response options for both of the two questions were as follows: "A. Excellent", "B. Very good", "C. Good", "D. Fair (neither good nor poor)", "E. Poor", "F. Very poor", "G. Extremely poor", and "H. Do not know". The options of these two questions were scaled to: Excellent $=7$, Very good $=6$, Good $=5$, Fair $=4$, Poor $=3$, Very poor $=2$, Extremely poor $=1$, Do not know $=0$. Higher values correspond to higher levels of health status. The respondent was identified experiencing Health Status Change if there were different choices in the options of two questions except option " $H$ " (i.e. picking option "A" for question one and choosing option "B" for question two). Meanwhile, the respondent was identified experiencing Health Status Improvement if choosing option "C" for question one and option "B" or "A" for question two. On the contrary, the respondent was identified experiencing Health Status Decline if choosing option "C" for question one and option "D" or "E" for question two.

Immigrant status of English or French or Chinese speaking subjects was identified by the response of "Original Country" question in the Questionnaire - "What is your country of origin?"

Demographic characteristics (independent variables) of the study population were identified according to response choice of the demographic questions relating to "Mother Tongue", "Speaking Language", "Age", "Gender", "Marital Status", "Category of Immigration", "Duration of Residence", "Education", "Employed Status", "Employed Status", "Primary Occupation", "Religion" and "Income" in the Questionnaire.

Data in Health Status Change were analyzed statistically for the different immigrant sub-groups in percentage, significance of difference, correlation and regression.

\subsection{Data Analysis Method}

Rates in Health Status Change were calculated respectively, which included Health Status Change Rate, Health Status Improving Rate and Health Status Declining Rate in the Total Sample, the Gender (Man and Woman) Sub-Groups, the Language (English, French and Chinese speaking) Sub-Groups and the Category (Principal Applicant Immigrant, Spouse and Dependant Immigrant, Family Class Immigrant, Other / Refugee Immigrant) Sub-Groups. Chi-square tests were performed to test if there was significant difference between the rates of immigrant sub-groups in Health Status Change. Following the descriptive analysis, correlation analysis was performed to 
test if there were correlation between demographic (independent) variables - Mother Tongue, Age, Gender, Category of Immigration, Duration of Residence, Employment Status, Primary Occupation, Religion, Income, and health status (dependent) variable - Health Status Change. Finally, multiple / multivariable linear regression analysis was used to determine if the independent variables had significantly impacted the dependent variable.

\section{Ethical Approval}

The immigrant health status change study was part of a multicultural lifestyle change research project that was approved by Social and Behavioural Research Ethics Committee, Flinders University in Australia in 2010 and by Office of Research Ethics and Integrity, University of Ottawa in Canada in 2014.

\section{Results}

Response rate of the multicultural survey was $95.51 \%$. Non-response rate was $4.48 \%$.

\subsection{Percentages in Health Status Change}

Table 1 presents the Health Status Change by population sub-groups.

\subsection{P Significance Level}

Table 2 presents significance level of Health Status Change Rates.

\subsection{Multivariate Analysis: Correlation and Regression}

Table 3 presents multivariate analysis results in Health Status Change.

Table 1. Rates of Total Sample and Different Sub-groups in Health Status Change

\begin{tabular}{|c|c|c|c|c|}
\hline & \multirow[b]{2}{*}{ Item } & \multicolumn{3}{|c|}{ Health Status Change } \\
\hline & & $\begin{array}{l}* \text { Health Status } \\
\text { Change rate \% }\end{array}$ & $\begin{array}{c}\text { Health Status } \\
\text { Improving rate \% }\end{array}$ & $\begin{array}{c}\text { Health Status } \\
\text { Declining Rate \% }\end{array}$ \\
\hline & Total Sample (810) & 75.31 & 40.74 & 34.57 \\
\hline Gender & Immigrant Men (411) & 75.18 & 42.82 & 32.36 \\
\hline Sub-groups & Immigrant Women (399) & 75.44 & 38.60 & 36.84 \\
\hline & English Immigrants (278) & 79.14 & 40.65 & 38.49 \\
\hline Language & French Immigrants (268) & 70.52 & 27.24 & 43.28 \\
\hline & Chinese Immigrants (264) & 76.14 & 54.55 & 21.59 \\
\hline & Principal Applicant Immigrants (193) & 80.83 & 52.85 & 27.98 \\
\hline Category & Spouse and Dependent Immigrants (193) & 68.39 & 37.31 & 31.09 \\
\hline Sub-groups & Family Class Immigrants (354) & 80.23 & 39.55 & 40.68 \\
\hline & Other (Refugee) Immigrants (70) & 54.29 & 22.86 & 31.43 \\
\hline
\end{tabular}

Notes: Notes: * Health Status Change Rate $=$ Health Status Change subjects / sampled subjects x $100 \%$

Table 2. Significance Level of Different Sub-groups in Health Status Change Rates

\begin{tabular}{|c|c|c|c|}
\hline Item & Chi-square & p-value & $\begin{array}{l}\text { Significant } \\
\text { Difference }\end{array}$ \\
\hline Health Status Change Rates of Male and Female Immigrant Sub-groups & 6.000 & 0.306 & No \\
\hline Health Status Change Rates of English, French and Chinese Immigrant Sub-groups & 18.000 & 0.324 & No \\
\hline $\begin{array}{l}\text { Health Status Change Rates of Principal Applicant, Spouse and Dependent, Family Class, } \\
\text { Other/Refugee Immigrant Sub-groups }\end{array}$ & 36.000 & 0.330 & No \\
\hline
\end{tabular}

Notes: Significance Level: $\mathrm{p}<0.05$

Table 3. Multivariate Analysis in Health Status Change

\begin{tabular}{|c|c|c|c|c|c|c|c|c|}
\hline \multicolumn{5}{|c|}{ Correlation Analysis } & \multicolumn{4}{|c|}{ Multiple Linear Regression Analysis } \\
\hline $\begin{array}{l}\text { Dependent } \\
\text { Variable }\end{array}$ & $\begin{array}{c}\text { Independent } \\
\text { Variable }\end{array}$ & Pearson's $r$ & $\mathrm{p}$-value & $\begin{array}{c}\text { Correlation } \\
\text { between } \\
\text { Independent } \\
\text { Variable and } \\
\text { Dependent } \\
\text { Variable }\end{array}$ & $\begin{array}{c}\text { Dependent } \\
\text { Variable }\end{array}$ & $\begin{array}{c}\text { Independent } \\
\text { Variable }\end{array}$ & $\mathrm{p}$-value & $\begin{array}{c}\text { Impact of } \\
\text { Independent } \\
\text { Variable on } \\
\text { Dependent } \\
\text { Variable }\end{array}$ \\
\hline \multirow{4}{*}{$\begin{array}{c}\text { Health Status } \\
\text { Change }\end{array}$} & Age & 0.414 & 0.000 & $\begin{array}{c}\text { Positive } \\
\text { Correlation }\end{array}$ & \multirow{4}{*}{$\begin{array}{l}\text { Health } \\
\text { Status } \\
\text { Change }\end{array}$} & $\begin{array}{l}\text { Mother } \\
\text { Tongue }\end{array}$ & 0.002 & $\begin{array}{l}\text { Significant } \\
\text { Impact }\end{array}$ \\
\hline & $\begin{array}{c}\text { Primary } \\
\text { Occupation }\end{array}$ & 0.310 & 0.000 & $\begin{array}{c}\text { Positive } \\
\text { Correlation }\end{array}$ & & Age & 0.000 & $\begin{array}{l}\text { Significant } \\
\text { Impact }\end{array}$ \\
\hline & \multirow{2}{*}{ Income } & \multirow{2}{*}{0.173} & \multirow{2}{*}{0.000} & \multirow{2}{*}{$\begin{array}{l}\text { Positive } \\
\text { Correlation }\end{array}$} & & $\begin{array}{c}\text { Primary } \\
\text { Occupation }\end{array}$ & 0.005 & $\begin{array}{l}\text { Significant } \\
\text { Impact }\end{array}$ \\
\hline & & & & & & Income & 0.002 & $\begin{array}{c}\text { Significant } \\
\text { Impact }\end{array}$ \\
\hline
\end{tabular}

Notes: Significance Level: $\mathrm{p}<0.05$ 


\section{Discussion}

Because the questionnaire administering mode "Self-administered questionnaires completed in the presence of research staff" was applied in the multicultural study [23, $24]$, or involvement of the principal surveyor and the survey assistants, the study had very high response rate $(96.54 \%)$, which was higher the general recommendation of survey experts for the response rate $(90 \%$ or higher) $[25,26]$. The results show that the immigrants experienced health status change. However, different gender, language and category sub-groups exhibited different Health Status Change, Health Status Improvement and Health Status Decline. Some of the demographic factors were correlated with health status change and significantly impacted health status change.

\subsection{Percentages}

\subsubsection{Total Sample}

The results show that most of the immigrants had Health Status Change after immigration, and their health status improving rate was higher health status declining rate. It appears that the immigrants in Canada could be healthier after immigration than before immigration. The finding of this health status change study supports "healthy immigrant effect" in Canada. However, some researchers suggest that the "healthy immigrant effect" might be more perceived than real and associated with the acculturation process [9, 27]. Meanwhile, other researcher indicates that year of arrival and region of origin may be important determinants of health and/or health status change [28].

\subsubsection{Gender Sub-groups}

The results reveal that immigrant men and women had almost the same Health Status Change Rates (75.18\% and $75.44 \%$ ), and no gender difference in health status change. However, Health Status Improving Rate (42.82\%) and Health Status Declining Rate $(32.36 \%)$ of the male immigrants were respectively higher and lower than those (38.6\% and $36.84 \%$ ) of the female immigrants, which appears that the male immigrants could be healthier than the female immigrants. Some of research findings reveal that female immigrants were significantly more likely than male immigrants to rate their health poorly and to report worse states of health, and could be at a very high risk of declining health status $[6,9,27]$. Similarly, other study reveals a strong "healthy immigrant effect" among new immigrant middle-aged men and a poorer health report among immigrant middle-aged women [29]. Nevertheless, a study indicates that female immigrants had better self-reported health than male immigrants, despite having worse functional health [30]. Moreover, health advantage of female immigrants decreased after over 10 years, but health advantage of male immigrants wore out after between 2 and 9 years $[27,31]$.

\subsubsection{Language Sub-groups}

It has been known that English Immigrants had the highest Health Status Change Rate (79.14\%), while Chinese Immigrants had higher Change Rate (76.14\%) and French Immigrants had the lowermost Change Rate (70.52\%). It is interesting to note that Chinese Immigrants had the highest Health Status Improving Rate (54.55\%), while English Immigrants had lower Improving Rate (40.65\%) and French Immigrants had the lowermost Improving Rate (27.24\%). However, French Immigrants had the highest Health Status Declining Rate (43.28\%), while English Immigrants had lower Declining Rate (38.49\%) and Chinese Immigrants had the lowermost Declining Rate $(21.59 \%)$. It appears that Chinese Immigrants could be healthier than English immigrants, but English Immigrants could be healthier than French Immigrants. Some of the research findings reveal that different ethnic and cultural immigrant groups or sub-groups experienced different health status change and certain groups or sub-groups had higher health status compared to other groups or sub-groups [5, 9, 32]. For example, recent non-English-speaking immigrants experienced a health advantage [27]. Similarly, some of visible-minority groups or sub-groups, such as Filipinos, Koreans, Blacks and Latinos, demonstrated better self-assessed health outcomes and more health advantage than non-visible minority groups or sub-groups, such as Jewish and South/East European ethnic groups [32]. Furthermore, some of ethnic and racial groups, such as South Asian, Black, Latin American and English, experienced better functional health compared with other groups or sub-groups, such as aboriginal, Jewish, mixed racial groups [30]. However, a National Population Health Survey in Canada discloses that the immigrants from Asia, Africa, or South America were less likely to report excellent or very good health status compared to the immigrants from Europe, Australia, New Zealand, the United States and Mexico [33, 34]. Analogously, some of the research findings in Canada reveal that recent non-European immigrants were twice as likely as Europeans to experience declines in self-assessed health $[5,9,10]$.

On the other hand, language preference and English language proficiency may exhibit different impacting effects on immigrant health status. For example, Spanish-speaking Hispanics in the US reported far worse health status than did English-speaking Hispanics [35].

\subsubsection{Category Sub-groups}

The results reveal that Principal Applicant Immigrants had the highest Health Status Change Rate $(80.83 \%)$ and Health Status Improving Rate (52.85\%), and Family Class Immigrants had the second highest Health Status Change Rate (80.23\%) and Health Status Improving Rate (39.55\%), while Spouse and Dependent Immigrants had lower Health Status Change Rates (68.39\%) and Health Status Improving Rate $(37.31 \%)$, and Other (Refugee) Immigrants had the lowermost Health Status Change Rates (54.29\%) and Health Status Improving Rate $(22.86 \%)$. However, Family Class Immigrants had the highest Health Status Declining Rate $(40.68 \%)$ and Other (Refugee) Immigrants had the second 
highest Health Status Declining Rate (31.43\%), while Spouse and Dependent Immigrants had lower Health Status Declining Rate (31.09\%) and Principal Applicant Immigrants had the lowermost Health Status Declining Rate $(27.98 \%)$. It is interesting to note that Health Status Improving Rate and Health Status Declining Rate of Spouse and Dependent Immigrants were respectively lower $2.24 \%$ and $9.59 \%$ than those of Family Class Immigrants. Meanwhile, Health Status Declining Rate and Health Status Improving Rate of Other (Refugee) Immigrants were respectively lower $9.25 \%$ and $16.69 \%$ than those of Family Class Immigrants. Thus, it appears that sequence of Health Status from good to poor could be Principal Applicant Immigrants, Spouse and Dependent Immigrants, Family Class Immigrants and Other (Refugee) Immigrants.

Immigrant health status data from Canadian government disclose that Principal Applicant Immigrants were more likely to be generally healthy, while refugees were more likely to rate their health status as fair or poor [32]. Refugees were more likely to report their health as fair or poor initially because they often come from areas of conflict with poor public health infrastructure and were more likely to be at risk for malnutrition and infectious diseases [34, 35]. Meanwhile, refugees could have experienced more financial and cultural barriers, which had negative effects on their health outcomes [36]. Thus, refugees have the least improvement of health status after immigration. For example, a Statistics Canada's Longitudinal survey discloses that refugees were observed to have lower levels of health and were more likely to transition to a state of poor health [37].

\subsection{Significance Level}

Though significance analysis shows that there was no statistical differences between rates of the sub-groups in Health Status Change, percent comparisons indicate substantial percentage differences between some of the rates.

\subsection{Multivariate Analysis}

The results of correlation analysis show that immigrant Health Status Change was correlated positively with Age, Primary Occupation and negatively with Income. Age, Primary Occupation and Income were determinants of the immigrants in Health Status Change. A recent survey in Canada shows that health conditions of immigrants were associated with age, sex, ethnic origin and income [36]. Meanwhile, the results of regression analysis disclose that Mother Tongue, Age, Primary Occupation and Income significantly impacted Health Status Change, and were main determinants in Health Status Change.

\subsection{Health Status Change and Income}

It has been observed in the multicultural study that Income significantly impacted Health Status Change. A research report indicates that Income was an important factor to influence disparity of immigrant health status [3, 6]. Some of findings show that immigrants with high incomes were more likely to report their health status as very good or excellent $[31,34]$, and low-income immigrants were at greatest risk of transitioning to poor health status [9]. Similarly, a Statistics Canada's Longitudinal survey discloses that economic immigrants reported the highest levels of self-assessed health [37].

\subsection{Health Status Change and "Healthy Immigrant Effect"}

The "healthy immigrant effect" observed in other countries also prevails in Canada. The effect is most evident among those from non-European countries, who constitute the majority of recent immigrants to Canada [39]. For example, a Canadian Community Health Survey indicates that the first-generation immigrants of Black and French ethnicity tended to have better health than their Canadian-born counterparts [29]. However, a case study report indicates that there was no health advantage for immigrants, nor a gradient of worsening health with time since immigration [40]. The results of this current study supported "healthy immigrant effect" in immigration countries and "Canadian immigrants, particularly recent immigrants, enjoyed a health advantage over both long-term immigrants and the Canadian-born population" $[5,6,27]$.

\subsection{Health Status Change and Health Advantage Decline}

It has been noted that immigrant health advantages decreased along with increasing length of residence in Canada [41]. Some of health research experts in Canada indicate that "healthy immigrant effect" tends to diminish over time [6, 40, 41, 42, 43, 44]. Some of surveys show that the "healthy immigrant effect" was stronger for recent $(<10$ years residence in Canada) immigrants [45], and immigrant health status declined significantly within two years or the first four years after arrival in Canada [44, 45, 46]. Many of factors may contribute the decline in health status, such as pre-/post-departure health elements [46], bio-geographical and socio-economic environmental changes $[47,48]$, lifestyle changes $[5,49,50,51,52]$, and acculturation $[45,53$, 54].

\subsection{Health Advantage Decline and Acculturation}

Declining health with time in the receiving countries of immigrants has been called an "acculturation effect" [55]. For instance, a recent report in the US exhibits that the first generation immigrants were less likely to rate their health as poor/fair than the third generation and more acculturated immigrants [56]. Similarly, other study reveal that the "healthy immigrant effect" may diminish with greater acculturation as the host culture potentially promotes more unhealthy weight gain than the heritage cultures [57]. 


\subsection{Health Advantage Decline in Certain Immigrant Sub-groups}

The results of this current study reveal that health status improving rate in some language sub-group (i.e. French immigrants) or some category sub-group (i.e. Other/Refugee immigrants) was lower than their health status declining rate. A Canadian study indicates that the "healthy immigrant effect" was only present in certain sub-groups of immigrants [11]. Similar evidence from the National Population Health Survey displays that the loss of 'healthy immigrant effect' may not be experienced equally by all immigrants in Canada [58]. Therefore, the authors suggest that "decline in immigrant health status" over time existed in some of immigrant sub-groups instead of all immigrants in Canada, and different immigrant groups or sub-groups could have disparities of health status change over time.

\section{Research Strengths and Limitations}

The multicultural survey is an unique immigrant health status change study, which discloses initiatively pre- and post-departure health status of different immigrant sub-groups, may fill partly gap of multicultural health status research, and can contribute greatly and significantly multicultural health research. The recall biases of immigrant health status before and since arrival in Canada were reduced effectively as the aids of the principal surveyor and the survey assistants. However, the study was a retrospective self-reported or proxy-reported health status change survey, and the degree to which some of the results could be inaccurate because of some of reporting errors were unknown. Meanwhile, "health status improving rate" and "health status declining rate" were not particularly useful metrics, and some of potential biases (i.e. purposive-sampling instead of random sampling, not enough large sample) and confounders (i.e. involvement of some of bi-lingual and/or multi-lingual immigrants) could include in the survey. Moreover, the study did not examine chronic conditions of immigrants. Thus, the study represents limitedly health status change of the immigrants at the region and has insufficient generalizability of immigrant health status change in Canada.

\section{Policy Implication}

The results of this immigrant health status change study can provide evidence for making and/or revising policies related to immigrant health in Canada, which may regulate or adjust health care and service for immigrants, and make more effectively health promotion program to improve immigrant health status and Canadian population health, to lessen immigrant risk of chronic diseases, and to reduce health inequality and inequity for immigrants. The data may help Health Canada policy makers to source and consider evidence of health status change for the vulnerable and marginalized populations in decision-making and policy-revising process, and to adapt appropriately evidence, prior to and during formulating new health policy or revising previous health policy. Thus, Canadian immigrants can improve their health and experience healthier status to contribute Canadian economic and social development.

\section{Conclusions}

The immigrants in Canada experienced changes in their health status. However, the changes in health status were moderated by gender, language, and immigrant categories, with different factors influencing to health status change. Mother Tongue, Primary Occupation and Income significantly impact health status change. Income was a particular important affecting factor. Acculturation was a possible contributing factor. The study results supported "healthy immigrant effect". The "decline in immigrant health status" over time existed in some of immigrant sub-groups. Data of immigrant health status change may provide evidence for population health policy-making and policy-revising in Canada.

\section{Acknowledgements}

The authors appreciate linguistic support of the bilingual teachers, Claude Couture and Denis Mascotto in Centre de formation professionnelle Vision-Avenir, Commission scolaire des Portages-de-l'Outaouais, Gatineau, Québec, Canada. In particular, the authors are very grateful to assistance of immigrant health expert, Dr. Brian Gushulak in Immigration Health Consultants in Canada.

\section{REFERENCES}

[1] Government of Canada. IMDB 2008 Immigration Category Profiles. 2012. Available at:

http://www.cic.gc.ca/english/resources/research/imdb2008-c at-profiles.asp .

[2] Government of Canada. Facts and figures. Government of Canada activities and initiatives. 2013. Available at: http://www.cic.gc.ca/english/resources/statistics/menu-fact.a $\mathrm{sp}$.

[3] G. Jasso, D. S. Massey, M. R. Rosenzweig and J. P. Smith. Critical Perspectives on Racial and Ethnic Differences in Health in Late Life: 7. Immigrant Health: Selectivity and Acculturation. National Research Council (US) Panel on Race, Ethnicity, and Health in Later Life. Washington (DC): National Academies Press (US); 2004. ISBN-10: 0-309-09211-6. Available at: http://www.ncbi.nlm.nih.gov/books/NBK25532/ and http:/www.ncbi.nlm.nih.gov/books/NBK25533/ . 
[4] J.H. Lassetter, L. C. Callister. The impact of migration on the health of voluntary migrants in Western societies. A review of the literature. J Transcult Nurs, 2009, 20: 1 (93-104). Available at: http://tcn.sagepub.com/content/20/1/ 93.abstract

http://www.ncbi.nlm.nih.gov/pubmed/18840884 .

[5] E. Ng, R. Wilkins, F. Gendron and J-M. Berthelot. (2005). Healthy today, healthy tomorrow? Findings from the National Population Health Survey: Dynamics of Immigrants' Health in Canada: Evidence from the National Population Health Survey. Component of Statistics Canada Catalogue no. 82-618-MWE2005002. Available at: http://www.statcan.gc.ca/pub/82-618-m/82-618-m2005002-e ng.htm or http://www.canpopsoc.org/journal/CSPv32n1p131 .pdf .

[6] B. Newbold, J. Danforth. Health status and Canada's immigrant population. Soc Sci Med, 2003 Nov, 57(10):1981-95. Available at: http://www.ncbi.nlm.nih.gov/pubmed/14499520 .

[7] De Maio FG \& Kemp E. The deterioration of health status among immigrants to Canada. Glob Public Health, 2010, 5: 5 (462-78). Available at:

http://www.ncbi.nlm.nih.gov/pubmed/19513909 .

[8] S. S. Halli, J. P. Anchan. Structural and behavioural determinants of immigrant and non-immigrant health status: Results from the Canadian community health survey. Journal of International Migration and Integration, 2005, 6: 1 (93-123). Available at:

http://www.springerlink.com/content/b784v0p47w542u11/ .

[9] K. B. Newbold. Health Status and Health Care of Immigrants in Canada: A Longitudinal Analysis. Journal of Health Services Research Policy, 2005a, 10: (2) 77-83a. Available at:

http://jhsrp.rsmjournals.com/cgi/content/abstract/10/2/77 .

[10] K. B. Newbold. 2005b. Self-rated health within the Canadian immigrant population: risk and the healthy immigrant effect. Soc Sci Med, 60: 6 (1359-1370). Available at: http://www.medscape.com/medline/abstract/15626530 .

[11] P. Bergeron, N. Auger, D. Hamel. Weight, general health and mental health: status of diverse subgroups of immigrants in Canada. Canadian Journal of Public Health, 2009 May-Jun; 100: 3 (215-200). Available at: http://www.ncbi.nlm.nih.gov/pubmed/19507726 .

[12] Statistics Canada. (2009a). Immigration in Canada: A Portrait of the Foreign-born Population, 2006 Census: Portraits of major metropolitan centres: Ottawa - Gatineau: Fifth-largest proportion of foreign-born. Available at http://www12.statcan.ca/census-recensement/2006/as-sa/97557/p23-eng.cfm .

[13] Statistics Canada (census). (2011). Population by mother tongue, by census metropolitan area, excluding institutional residents, 2006 census metropolitan area. Available at: http://www.statcan.gc.ca/tables-tableaux/sum-som/101/cst01/ demo12c-eng.htm

[14] J-O. Roy, C. Belkhodja, N. Gallant. Nos diverses cites: Immigration francophone en milieu minoritaire : le défi de la ruralité. 2007, Université Concordia, Canada. Available at: http://nre.concordia.ca/ ftp2004/featured publication/ODC _Summer07_3_fr.pdf\#page $=89$.

[15] G. Man. Gender, work and migration: Deskilling Chinese immigrant women in Canada. Women's Studies International Forum, 2004, 27: 2 (135-148). Available at: http://www.sciencedirect.com/science/article/pii/S02775395 04000172 .

[16] C. Lu, J. Sylvestre, N. Melnychuck, J. Li. East meets West: Chinese-Canadians perspectives on health and fitness. Canadian Journal of Public Health, 2008, 99: 1 (22-25). Available at:

http://www.ncbi.nlm.nih.gov/pubmed/18435385 .

[17] Kennedy S, McDonald JT and Biddle N. The Healthy Immigrant Effect and Immigrant Selection: Evidence From Four Counties. 2006. JEL: I12, I00, J61. Available at: http://www.docstoc.com/docs/31851096/THE-HEALTHY-I MMIGRANT-EFFECT-AND-IMMIGRANT-SELECTIONEVIDENCE .

[18] A. L. Comfrey, H. B. Lee. (1992). A First Course in Factor Analysis. Hillsdale, NJ: Lawrence Erlbaum Associates. Available at: http://www.tandfonline.com/doi/abs/10.1080/00401706.199 3.10485363

[19] Y. S. Ryu, T. L. Smith-Jackson. Reliability and Validity of the Mobile Phone Usability Questionnaire (MPUQ). Journal of Usability Studies, 2006, 2: 1 (39-53). Available at: http://www.upassoc.org/upa_publications/jus/2006_novemb er/ryu smith-jackson mobile phone questionnaire.pdf .

[20] S-E. Eshaghi, M. A. Ramezani, A. Shahsanaee and A Pooya. Validity and Reliability of the Short Form- 36 Items Questionnaire as a Measure of Quality of Life in Elderly Iranian Population. American Journal of Applied Sciences, 2006, 3: 3 (1763-1766). Available at: http://thescipub.com/PDF/ajassp.2006.1763.1766.pdf .

[21] O. M. Ekeberg, E. Bautz-Holter, E. K. Tveitå, A. Keller, N. J. Juel and J. I. Brox. Agreement, reliability and validity in 3 shoulder questionnaires in patients with rotator cuff disease. BMC Musculoskeletal Disorders 2008, 9:68. Available at: http://www.biomedcentral.com/1471-2474/9/68 .

[22] C. Hopkins, J. Fairley, M. Yung, I. Hore, S. Galasubramaniam, M. Haggard. The 14-item Paediatric Throat Disorders Outcome Test: a valid, sensitive, reliable, parent-reported outcome measure for paediatric throat disorders. The Journal of Laryngology \& Otology (2010), 124, 306-314. Available at:

http://journals.cambridge.org/download.php?file $=\% 2 \mathrm{FJLO} \%$ 2FJLO124 03\%2FS0022215109992386a.pdf\&code $=$ ea89a4 dd63b9103cb1a15cd526574854.

[23] I. Schoon. Questionnaire design. In: Nunn J, editor. Laboratory psychology: a beginner's guide. New York: Psychology Press; 1998: 73-96. Available at: http://www.amazon.com/Laboratory-Psychology-BeginnersGuide-Cognitive/dp/0863777112 .

[24] Centers for Disease Control and Prevention (CDC), US. 2003. Questionnaire Design: Reproductive Health, Epidemiology Series: Module 4. US Department of Health and Human Services, CDC. Available at: http://www.cdc.gov/reproductivehealth/ProductsPubs/PDFs/ Epi_Module_04_Tag508.pdf.

[25] J. Jones. The effects of non-response on statistical inference. J Health Soc Policy, 1996, 8: 1 (49-62). Available at: http://www.ncbi.nlm.nih.gov/pubmed/10162904

[26] H. Tolonen. Towards the High Quality of Population Health 
Surveys: Standardization and Quality Control. National Public Health Institute, A27/2005, Helsinki, Finland, and Faculty of Medicine, University of Kuopio, Finland. Available at:

http://wanda.uef.fi/uku-vaitokset/vaitokset/2006/isbn951-74 0-545-4.pdf .

[27] I. Hyman. Immigration and Health: Reviewing Evidence of the Healthy Immigrant Effect in Canada. CERIS Working Paper No. 55, Joint Centre of Excellence for Research on Immigration and Settlement - Toronto, 2007. Available at: http://ceris.metropolis.net/wp-content/uploads/pdf/research_ publication/working_papers/wp55.pdf .

[28] J. T. McDonald, S., Kennedy. Insights into the 'healthy immigrant effect': health status and health service use of immigrants to Canada. Soc Sci Med, 2004, 59(8):1613-1627. . Available at:

http://www.eifzvip.cz/dokumenty/elektronicka knihovna/Ins ights_into_healthy_immigrant_effect_-_Canada.pdf.

[29] K.M. Kobayashi and S. G. Prus. Examining the gender, ethnicity, and age dimensions of the healthy immigrant effect: Factors in the development of equitable health policy. International Journal for Equity in Health. 2012, 11:8. Available at: http://www.equityhealthj.com/content/11/1/8 .

[30] Z. Wu and C. M. Schimmele. Racial/Ethnic Variation in Functional and Self-reported Health. American Journal of Public Health, 2005, 95 (4): 710-716. Available at: http://www.ncbi.nlm.nih.gov/pmc/articles/PMC1449245/ .

[31] B. Vissandjee, I. Hyman, D. L. Spitzer, A. Apale and N. Kamrun. Integration, Clarification, Substantiation: Sex, Gender, Ethnicity and Migration as Social Determinants of Women's Health. Journal of International Women's Studies, 2007, 8(4): 32-48. Available at: http://vc.bridgew.edu/jiws/vol8/iss $4 / 3$.

[32] S. Prus and Z. Lin. 2005. Ethnicity and Health: An Analysis of Physical Health Differences across Twenty-one Ethnocultural Groups in Canada. SEDAP Research Paper No. 143. Social and Economic Dimension of an Aging Population (SEDAP) Research Program. Retrieved from: http://socserv2.mcmaster.ca/sedap/p/sedap143.pdf

[33] J.R. Dunn, I. Dyck. Social determinants of health in Canada's immigrant population: Results from the National Population Health Survey. Soc Sci Med, 2000, 51: 11 (1573-1593). Available at: http://www.ncbi.nlm.nih.gov/pubmed/11072880.

[34] J. S. Ali. McDermott S, Gravel RG. Recent Research on Immigrant Health from Statistics Canada's Population Surveys. Canadian Journal of Public Health, 2004, 95:3 (9-13). Available at: http://www.ncbi.nlm.nih.gov/pubmed/15191126 .

[35] C. A. DuBard and Z. Gizlice. Language spoken and differences in health status, access to care, and receipt of preventive services among US Hispanics. American Journal of Public Health, 2008 November, 98: 11 (2021-2028). Available at: http://www.ncbi.nlm.nih.gov/pmc/articles/PMC2636430/ .

[36] J. Zhao, L. Xue and T. Gilkinson. Health Status and Social Capital of Recent Immigrants in Canada: Evidence from the Longitudinal Survey of Immigrants to Canada. 2010. Available at: http://www.cic.gc.ca/english//resources/research/immigrant- survey/index.asp .

[37] K. B. Newbold. The short-term health of Canada's new immigrant arrivals: evidence from LSIC. Ethnicity \& Health, 2009, 14: 3 (315-336). Available at: http://www.tandfonline.com/doi/abs/10.1080/135578508026 09956\#.VDyLwuktCM9

[38] R.P. Subedi, M. W. Rosenberg. Determinants of the variations in self-reported health status among recent and more established immigrants in Canada. Soc Sci Med. 2014, 115:103-10. Available at: http://www.ncbi.nlm.nih.gov/pubmed/24953500 .

[39] J. Chen, E. Ng and R. Wilkins. The Health of Canada's Immigrants in 1994-95. Health Statistics Division at Statistics Canada. Health Reports, Spring 1996, 7:4 (33-45). Available at: http:/www.ncbi.nlm.nih.gov/pubmed/8679956 .

[40] C. E. Pérez. Health Status and Health Behaviour Among Immigrants. Statistics Canada, Catalogue 82-003. Supplement to Health Reports, volume 13, 2002. Available at:

http://www.statcan.gc.ca/pub/82-003-s/2002001/pdf/82-003s2002005-eng.pdf .

[41] Z. Y. Sun, H. Xiog, X.M. Zhan, G. W. Huang, P. Z. Wang. The health status of Asian immigrants and the associated factors in Canada. Chinese Journal of Epidemiology, Apr 2009; 30(4):360-4. Available at: http://www.ncbi.nlm.nih.gov/pubmed/19731528 .

[42] E. M. Gee, K. M. Kobayashi, S. D. Prus. Examining the Healthy Immigrant Effect in Mid- To Later Life: Findings from the Canadian Community Health Survey. Canadian Journal on Aging, 2004, 23: S55-S63. Available at: http://socserv.mcmaster.ca/sedap/p/sedap98.pdf or http://ww w3.carleton.ca/casr/gee.pdf .

[43] E. Fuller-Thomson, A. M. Noack, U. George. Health decline among recent immigrants to Canada: findings from a nationally-representative longitudinal survey. Canadian Journal of Public Health, 2011, 102: 4 (273-80). Available at: http://reference.medscape.com/medline/abstract/21913582.

[44] D. Sanou, E. O’Reilly, I. Ngnie-Tega, M. Batal, N. Mondain, C. Andrew, B. K. Newbold, I. L. Bourgeault. Acculturation and Nutritional Health of Immigrants in Canada: A Scoping Review. Journal of Immigrant and Minority Health, February 2014, 16: 1 (24-34). Available at: http://link.springer.com/article/10.1007/s10903-013-9823-7/f ulltext.html .

[45] Z. Vang, J. Sigouin, A. Flenon, A. Gagnon. The Healthy Immigrant Effect in Canada: A Systematic Review. Population Change and Lifecourse Strategic Knowledge Cluster Discussion Paper Series/ Un Réseau stratégique de connaissances Changements de population et parcours de vie Document de travail. March, 2015, Vol. 3: Iss. 1, Article 4. Available at: http://ir.lib.uwo.ca/pclc/vol3/iss1/4 .

[46] V. P. Keane, B. D. Gushulak. The medical assessment of migrants: current limitations and future potential. International Migration, 2001, 39: 2 (29-42). Available at: http://onlinelibrary.wiley.com/doi/10.1111/1468-2435.00148 /abstract.

[47] W. P. Frisbie, Y. Cho, R. A. Hummer. Immigration and the health of Asian and Pacific Islander adults in the United States. Am J Epidemiol, 2001 Feb, 153: 4 (372-380). 
Available at: http://www.ncbi.nlm.nih.gov/pubmed/1120715 5 .

[48] Y. Cho, W. P. Frisbie, R. A. Hummer, R. G. Rogers. Nativity, duration of residence, and the health of Hispanic adults in the United States. Int Migr Rev, 2004 March, 38: 1 (184-211). Available at: http://onlinelibrary.wiley.com/doi/1 0.1111/j.1747-7379.2004.tb00193.x/abstract .

[49] I. R. Akresh. Dietary assimilation and health among Hispanic immigrants to the United States. J Health Soc Behav, 2007 Dec, 48: 4 (404-417). Available at: http://www.ncbi.nlm.nih.gov/pubmed/18198687 .

[50] G. K. Singh, S. M. Yu, M. Siahpush, M. D. Kogan. High levels of physical inactivity and sedentary behaviors among US immigrant children and adolescents. Arch Pediatr Adolesc Med, 2008 Aug, 162: 8 (756-763). Available at: http://www.ncbi.nlm.nih.gov/pubmed/18678808 .

[51] F. G. De Maio. Immigration as pathogenic: a systematic review of the health of immigrants to Canada. International Journal for Equity in Health, 2010, 9:27. Available at: http://www.equityhealthj.com/content/9/1/27\#B5 .

[52] S. Lee, A. H. O'Neill, E. S. Ihara, D. H. Chae. Change in Self-Reported Health Status among Immigrants in the United States: Associations with Measures of Acculturation. PLOS, October 2013. DOI: 10.1371/journal.pone.0076494. Available at: http://journals.plos.org/plosone/article?id=10.1371/journal.p one.0076494

[53] J. A. Dean, K. Wilson. "My health has improved because I always have everything I need here...": A qualitative exploration of health improvement and decline among immigrants. Socoal Science \& Medicine, 2010, 70: 8
(1219-1228). Available at: http://www.sciencedirect.com/science/article/pii/S02779536 $1000078 X ? \mathrm{np}=\mathrm{y}$

[54] B. D. Gushulak, D. W. MacPherson. Health Aspects of the Pre-Departure Phase of Migration. PLoS Med, 2011, 8(5): e1001035.doi:10.1371/journal.pmed.1001035. Available at: http://www.plosmedicine.org/article/info\%3Adoi\%2F10.137 1\%2Fjournal.pmed.1001035?utm_source=feedburner\&utm medium $=$ feed\&utm_campaign $=$ Feed $\% 3 \mathrm{~A}+$ plosmedicine $\% 2$ FNewArticles+\%28Ambra+-+Medicine+New+Articles $\% 29$.

[55] B. K. Finch, D. P. Do, R. Frank, T. Seeman. Could "Acculturation" Effects Be Explained by Latent Health Disadvantages Among Mexican Immigrants? International Migration Review, 2009, 43: 3 (471-495). Available at: http://www-rohan.sdsu.edu/ cherp/docs/imr_43_3.pdf .

[56] D. Acevedo-Garcia, L. M. Bates, T.L. Osypuk, N. McArdle. The effect of immigrant generation and duration on self-rated health among US adults 2003-2007. Soc Sci Med, 2010 Sep, 71: 6 (1161-1172). Available at: http://www.ncbi.nlm.nih.gov/pubmed/20624666 .

[57] M. Delavari, A. L. Sønderlund, B. Swinburn, D. Mellor and A. Renzaho. Acculturation and obesity among migrant populations in high income countries - a systematic review. BMC Public Health, 2013 May, 13:458. doi:10.1186/1471-2458-13-458. Available at: http://www.biomedcentral.com/1471-2458/13/458 .

[58] J. A. Satia. Diet-related disparities: understanding the problem and accelerating solutions. J Am Diet Assoc, 2009 Apr, 109: 4 (610-615). Available at: http://www.ncbi.nlm.nih.gov/pmc/articles/PMC2729116/?to ol=pubmed. 